\title{
Counter-ideological forces of "Mr Gate" in online Journalism in Malaysia: A study of MalaysiaKini and The Malaysian Insider
}

\author{
Mohd Faizal Kasmani ${ }^{1, *}$, Rosidayu Sabran $^{1}$, Siti Suriani Othman ${ }^{1}$ and Noor Adzrah Ramle ${ }^{1}$ \\ ${ }^{1}$ Universiti Sains Islam Malaysia, Bandar Baru Nilai, 71800, Negeri Sembilan
}

\begin{abstract}
The online news media are said to have changed the understanding of the gatekeeping theory. Due to the virtually unlimited news space together with the interactivity in the online presentation of news, the Internet defies the whole conception of gatekeeping in journalism. This article seeks to examine the influence of gatekeeping forces in two influential Malaysian online news portals, MalaysiaKini and The Malaysian Insider (TMI), during the 2013 Malaysian general election. Based on the hierarchical model of news conception, this study assessed the influence of ideological gatekeeping forces on their news content. The reporting by both news portals was subjected to qualitative textual analysis. The results are triangualted with interviews with corresponding reporters and editors from MalaysiaKini and TMI. The findings show that although the reporting of MalaysiaKini and TMI is counter-ideological, the gatekeeping process remains intact. This is due to the speed factor and the requirement of the news portals to abide by the media-related laws in Malaysia.
\end{abstract}

\section{Introduction}

Gatekeeping theory is one of the most enduring theories in mass communication and has informed the study of journalism for more than 60 years. Derived from the channel metaphor by Lewin [15], it was first introduced as a masscommunication concept by Manning [17]. Manning posited that 'Mr Gates', which mostly referred to the newspaper editor, decides which news is rejected and which will be published. At the same time, the gatekeeping practices also explain the power and influence of news editors over the news agenda. Editors basically maintain total control of the news agenda by deciding what should be published or rejected on behalf of news audiences[7].

Subsequent studies indicate that gatekeeping is actually a complex process in which news productions are filtered by a number of factors, such as the professional routines of journalists and the organisational structure [8,11,23] Gatekeeping, therefore, is seen as more of a group effort with multiple gates within the newsroom [8,25]. In 2000, Shoemaker and Reese [23] further refined the gatekeeping theory by introducing the hierarchical model of news influences, which allows for the study of gatekeeping on five levels of analysis: individual, routine, organisational characteristics, extra-media, and ideological.

The hierarchical aspect works in the way that each of the preceding forces may be thought to subsume the one before, suggesting that the ultimate level should be an ideological perspective [21,22]. The ideological level is concerned with how the media's symbolic content is connected with larger social interests and how meaning is constructed in the service of power. This necessarily leads us to consider that the recruitment of journalists, their attitudes, the routines they follow, their organisations' policy, and those organisations' positions in the larger social structure work to support the status quo. It means narrowing the range of social discourse by making the media agencies part of social control [22].

The Internet news media are said to have changed the understanding of the gatekeeping theory. Due to the Internet's virtually unlimited newshole, interactivity, and feedback available to readers of the online presentation of news, many scholars have written about how the online newspaper would challenge the gatekeeping concept in traditional media $[10,24]$. Interactivity in particular is said to have changed the power relations between journalists and audiences, where consumers have the ability to move at will through content and engage in computer-mediated conversations through the website [10].

For that reason, this article seeks to examine the influence of gatekeeping forces at ideological levels in online news portals. The reporting of two influential Malaysian online news portals, MalaysiaKini and The Malaysian Insider (TMI), during the 2013 Malaysian general election is used as a case study. The Malaysian Digital Association (MDA) and the comScore report for September 2015 showed that MalaysiaKini was the most visited news website and TMI the third

\footnotetext{
* Corresponding author: faizalkasmani@usim.edu.my
} 
most popular news website in Malaysia. To investigate this subject, this article presents and analyses the reporting of the 2013 Malaysian general election together with interviews with the editors of MalaysiaKini and TMI.

\section{Hierarchy of influence: the ideological forces}

Reese and Shoemaker [23] argue that in understanding how the news is 'constructed', there are many forces at work that influence the news content. Their hierarchy of influences model suggests a framework for analysing media based on levels of analysis, from the most micro to the most macro - namely, individual, routines, organisational, extramedia, and ideological. It describes the multiple levels of influences that impinge on media simultaneously and suggests how each level interacts with the others [23] at different levels of strength in any shaping of media content.

The individual level considers the attitudes, training, and background of the journalist (or media worker, more generally) as influential. The routines level of analysis considers the journalistic routines that are structured, deeply naturalised rules, norms, and procedures that are embedded in newsmaking. The organisational level considers the imperatives that give rise to journalistic routines and how individuals are obliged to relate to others within that larger formal structure. The extra-media level looks at the influences from outside the media organisation to shape the news content, including the government, advertisers, public relations, influential news sources, interest groups, and even other media organisations [22]. The ideological force is seen as the highest level of the hierarchy of influences model. At this level, the media is said to construct common-sense understandings in media content that attach to certain interests of groups in power, which control significant social resources. This is made to appear natural with the meanings that people have become accustomed to [21]. Such 'common sense' meaning in the representation of news discourse could be seen as ideological. The concept of ideology in this context refers to a mediated ideology: it concerns how newsmakers represent the world in ways that make sense to the public, but the construction of the common sense is 'the view of those with most power in society' [19]. Fairclough [13] points out that the concept of ideology in media discourse is related to the nature of power relations between media and the existing power holders.

\section{Methodology}

This article analyses the reporting of MalaysiaKini and TMI during the 13th Malaysian general election. MalaysiaKini was formed by Steven Gan and Premesh Chandran in November 1999. Both were former reporters at the Kuala Lumpur newspaper The Sun [26]. MalaysiaKini started as a free service and initially received funding from press-freedom and democracy-advocacy groups, namely the Southeast Asian Press Alliance (SEAPA) and the Media Development Loan Fund (MDLF). In 2004 it became a subscription service [2, 26].

TMI began publishing in February 2008 and was owned by TMIDOTCOM Sdn Bhd until it was acquired by The Edge Media Group in June 2014. It describes itself as a news portal 'which offers an unvarnished take on events and personalities in Malaysia' [3]. It was reported that TMI was originally financed by a group of businessmen close to the then Prime Minister, Tun Abdullah Ahmad Badawi. Initially, it was supposed to act as a counterbalance to MalaysiaKini, which was seen as unfriendly to the Barisan Nasional [28]. Throughout the years, alongside MalaysiaKini, TMI has been regarded as an independent online news media in Malaysia giving voices by alternative views, filling a void left by pro-government traditional media.

Samples of news packages on the 2013 Malaysian general election from MalaysiaKini and TMI were accessed on each news portal. The timeframe for the sample selection covered one week between 1 May 2013 and 7 May 2013. The samples spanned four days before and two days after the election, which represented not only a critical time of active campaigning by both the opposition and the government but also the reactions to the election results in the aftermath. Samples were chosen from the NEWS section of MalaysiaKini and the HOME section of TMI. This section was known for including breaking news, and the choice of writing styles was of particular interest for the purpose of the study.

This article assesses the influence of ideological gatekeeping forces on the content of both MalaysiaKini and TMI. Their news reporting was subjected to qualitative analysis. Selected articles are analysed, and the analysis of textual features of the news was based on the analysis of the lexical features, sentence construction of texts, and analysis of direct and indirect quotations. The findings from the textual analysis are triangulated with personal interviews with reporters and editors of MalaysiaKini and TMI who produced news packages during the 2013 election. Four interviews were conducted with reporters and editors of MalaysiaKini and TMI around the state of Selangor and Kuala Lumpur between April and October 2015. The interviewees are Steven Gan, the editor-in-chief and the co-founder of Malaysiakini; Hafiz Yatim, a journalist and an assistant editor of the English desk at Malaysiakini; Jahabar Sadiq, the chief executive and the editor-in-chief of TMI and Zurairi Abd Rahman, a senior journalist of TMI. The interviews lasted between 30 minutes and one hour. The interviews were semi-structured, with follow-up questions added as the interviews unravelled. The questions focused mainly on the factors that shaped the news coverage of both news portals during the 2013 general election. The interviews were recorded and transcribed for analysis.

\section{Analysis}


There were 288 and 189 articles on the Malaysian general election produced by MalaysiaKini and TMI, respectively, during the period from 1 May 2013 to 7 May 2013. Of the 288 articles produced by MalaysiaKini, more than $23 \%$ (55 articles) comprised syndicated articles from a local news agency, BERNAMA, or news agencies such as Reuters and Bloomberg (10 articles). More than 10\% (33 articles) were written by foreign columnists. Twenty-six of the articles were in the form of a review on readers' comments, collated and sorted by the editor according to the topics of the day; 6 of the articles documented chronological events or provided background information on the election. This means that during the 2013 general election, 156 of the articles, or about $55 \%$ of the overall articles, were produced by journalists from MalaysiaKini in the format of hard news.

Of the 189 articles produced by TMI, more than 30\% (60 articles) were syndicated from BERNAMA, with less than $3 \%$ from other news agencies such as Reuters and Bloomberg. Almost 10\% of the overall output (18 articles) was written by external columnists. Only 106, or 56\%, of the overall articles of TMI during the 2013 Malaysian general election were written by its in-house journalists.

In terms of diversity of sources for the news reports, there were a total of 163 sources for MalaysiaKini and 100 sources for TMI (which excluded the editorial writing from the columnists as well as other types of articles). All of the sources were cited and attributed. Most of the sources for MalaysiaKini were representatives of Pakatan Rakyat, comprising $28 \%$ of the overall sources. Sources from the ruling party, Barisan Nasional, came in at second place with $21 \%$. However, it is important to note that half of the sources from Barisan Nasional cited in MalaysiaKini were attributable to news syndicated from BERNAMA.

The majority of direct quotations in TMI were from Barisan Nasional. However, similarly to MalaysiaKini, the majority of the sources (24\%) from Barisan Nasional were attributable to syndicated news from BERNAMA. This means that news written by TMI reporters represented only $12 \%$ of the sources from Barisan Nasional. As with MalaysiaKini, the majority of news sources provided by in-house journalists was from Pakatan Rakyat (19\%).

Both news portals also gave voices to BERSIH, a coalition of non-governmental organisations (NGOs) that aims to reform the current electoral system in Malaysia to ensure free, transparent, and fair elections. Sources from the Malaysian Electoral Commission were also quoted by both news portals, although at less than 5\% of the overall news sources. Both news portals seemed to have a similar strategy in terms of the representation of sources from Barisan Nasional and the opposition party Pakatan Rakyat. Although from the outset there was not much disparity in terms of the representation of sources from the ruling and the opposition parties - and for TMI it appears that there were more sources from Barisan Nasional - the majority of the sources from the ruling party were provided by BERNAMA. BERNAMA, a government-owned agency, was seen as the most important provider of news for mainstream news media in Malaysia. It was also found to function as a conduit between the government and the local mass media. There are two possible reasons why news syndicated from BERNAMA appeared prominently on both websites. Firstly, it made the news portals appear balanced in terms of representation of sources. The news portal primarily represented voices from the opposition groups, therefore, syndicating news from BERNAMA provided the voice of the government. Secondly, reporters of MalaysiaKini and TMI may have had difficulty gaining access to the sources from Barisan National because of their reputations as being pro-opposition party. Thus, receiving content from BERNAMA was a way to represent the story from the side of the ruling party.

The analysis of the selected articles from MalaysiaKini and TMI included lexical features and sentence construction in texts. Four articles were selected for textual analysis based on several key events occurring before, during, and after the election and which had been covered by both MalaysiaKini and TMI. The issues covered the campaign trails, the results of the election, and commentary on Najib's statement that the poor performance of the ruling parties was due to the "Chinese Tsunami". Consistently with the quantitative analysis, MalaysiaKini and TMI clearly gave a voice to the opposition party, which had generally been ignored by the mainstream media in Malaysia. However, there were disparities in the lexical structure of MalaysiaKini and TMI reports on the two political parties. Although both platforms relied heavily on direct quotations and indirect quotations from the opposition group, TMI adopted a less critical tone towards Barisan Nasional and its leader Najib Razak. This was best illustrated by reporting on the results of a survey by the Merdeka Centre for Opinion Research on 3 March 2013. MalaysiaKini adopted a more critical tone to coverage of the ruling party and its leader [18]. The report of the poll results opened with the lead "BN chief Najib Abdul Razak's approval rating sliding down a further 3\% since the last poll". It then followed with a statement: "Pakatan Rakyat ahead of BN in terms of the favoured party to form the government". The report further explained that the statistic "reflect[ed] the slide in the 'feel good' factor that was previously generated by the large-scale distribution of Bantuan Rakyat's 1Malaysia (BRIM)".

TMI took a different angle when covering the story. The lead opened with "Barisan Nasional and Pakatan Rakyat are almost evenly tied to win Election 2013" [27]. It then explained that the polls showed that $42 \%$ had chosen Pakatan Rakyat to lead the government as against $41 \%$ for Barisan Nasional whereas $13 \%$ of voters remained undecided. The finding that the approval rating of Prime Minister, Datuk Seri Najib Razak, had slipped was mentioned in the second half of the story, reflecting a decision to give this fact less prominence than MalaysiaKini had done. MalaysiaKini's attitude when reporting on the poll results with respect to Barisan Nasional's chances of winning the election was also reflected in the news headline. It wrote "Najib's rating slides, BR1M not working", which showed the use of negative verbs towards the subject. In contrast, TMI reported "BN, Pakatan in dead heat for Election 2013", which showed that the news portal preferred to refrain from predicting the poll results.

MalaysiaKini's [16] report on Anwar's campaign a day before the election further showed the opposition's indirect quotations in Paragraphs 1-5. Anwar's statements were paraphrased using the verbs "vowed", "urged", and "repeated 
[his warning]", indicating, according to Barkho [5], "how the writer intrude[d] the event via what amount[d] to an evaluative comment". This demonstrated that MalaysiaKini's discursive patterns were closer to Anwar's viewpoints and his interpretation of events. In addition, the use of direct quotation at the end of the news report - "seize your destiny. Ini Kalilah!" - without any further attribution showed the reporter's support of Anwar's standing and position. TMI, on the other hand, gave a more detached reporting of the same event, as was shown in paragraphs 6-8 [20]. Except for one positive verb - "assured" - the rest of the coverage used the verbs "say" and "call", which carried little indication of the reporter's attitude towards Anwar's campaign and showed neither endorsement nor disparagement of his statements [9]

- ... de facto PKR leader Anwar Ibrahim urged the country's 13 million voters to turn up and cast their ballots with "faith, courage and vision" [16]

- He also urged them not to get involved in the shredding or hiding of government documents if Pakatan were to seize Putrajaya from the BN tomorrow, after polling day [16]

- He also urged Malaysians not to fear [16]

- $\quad$... he said in assurance [16]

- He repeated his warning to the Election Commission... [16]

- ...Pakatan Rakyat (PR) leader, Datuk Seri Anwar Ibrahim, assured the public that if his coalition wins Putrajaya, the transition will not only be historic but also peaceful [20]

- $\quad . .$. he said in a final press conference at Yayasan Aman here [20]

- Anwar called on the Election Commission to ensure a clean and fair election [20]

\section{Discussion}

Findings show that both TMI and MalaysiaKini provided alternative news reportage and analysis, which give competing discourses on political issues in Malaysia and challenge the version of the political reality as constructed by the mainstream media [14]. This is in contrast with media in Malaysia that was generally biased in favour of the ruling party [4]. During general elections, in particular, Malaysia's mainstream media were tasked with highlighting the Barisan Nasional government's successes, especially in the area of socioeconomic development. At the same time, adverting to the successes of other contesting political parties was restricted. If such parties appeared on the mainstream news, they were often depicted in a negative light [4]. This is in line with arguments by Steele [26] that specifically described MalaysiaKini, in particular, as legitimising 'alternative views of events, thus challenging the authoritarianism of the Barisan Nasional' (p. 91). Abbott [1] regarded MalaysiaKini as an example of the manner in which the Internet may have 'a democratising effect on the region's authoritarian and semi-authoritarian regimes by opening up a permissive online public sphere in which traditional hierarchies of power are challenged' (p. 333).

This counter-discourses coverage by TMI and MalaysiaKini is clearly part of journalistic ideology by both news editors. For MalaysiaKini's Steven Gan and TMI's Jahabar Sadiq, they view their news portal as breaking the deeply naturalised practice in Malaysian journalism of upholding only the official voices in the mainstream media. They also see themselves as breaking the 'common sense' meaning in the political news by presenting contending voices on political issues to ensure fair debates within Malaysian election discourse.

I feel very strongly that in a society like Malaysia where we are very divided, where people feel very strongly about things and have different viewpoints, we really need to come together and discuss them. We may at the end of the day agree to disagree, but what is important is that we know where we stand and where they stand on issues, and hopefully through that process, everyone comes a bit closer... (Steven Gan, personal interview, 20 May 2015)

Why are Bernama, TV3, and RTM covering issues mainly from the perspective of the government or Barisan Nasional leaders and not so much from that of the opposition leaders? So we are a mirror reflection of the mainstream media...we try to balance the coverage ... (Jahabar Sadiq, personal interview, 26 October 2015)

Both editors believe that in doing so they need to go back to the traditional practices of journalism of presenting facts to ensure that they report objectively and impartially. This also means the inverted pyramid technique - whereby journalists organise information from the most relevant at the top to the least relevant at the bottom — is the prioritised way of presenting news. It is in contrast with arguments that online news tends to incorporate a more conversational and narrative approach to news, indicating a more interpretative style of news writing that signifies a move away from the rigid news writing format.

...we report the facts of the day, issues of the day, as impartially as possible and as dispassionately as possible. This is the news. We clearly identify this is an opinion. We do not editorialise the news. The Malaysian Insider was set up in 2008 for the simple purpose of informing people so they can make informed choices and to give as much balance wherever possible in everything we cover. This is done in a very clinical way through journalism; this is news, and this is what is happening. This is a quote and this is what is happening. (Jahabar Sadiq, personal interview, 26 October 2015)

... when it comes to reporting news, when we are writing news, doing interviews, etc., we stick by the book. We 
have journalistic ethics, and we stick to them. When we write news, of course, we cannot concoct whatever a person says in order to give a story our own slant. That would be breaking journalistic ethics. We need to be fair in the sense that we will get the other side to rebut and to respond. (Steven Gan, personal interview, 20 May 2015)

Going back to traditional journalism means that both online news portals very much stick to the gatekeeping practice where every news item needs to go through the editorial team. MalaysiaKini, however, as explained by Steven Gan and its journalist Abdul Hafiz Yatim, appears to have a more democratic style of management. This could also explain why the journalists' voices of MalaysiaKini occasionally appear in the reporting.

Most of the time we discuss an issue and then let Steven Gan make the decision. At our office, all of the officers, including the Chinese, Malay, and English, sit together without any segregation. In fact, Steven Gan also sits with us. We are a flat organisation. (Abdul Hafiz, personal interview, 20 May 2015)

There is communication between journalists and editor, and this is partly because there has to be checks and balances. A lot of our journalists are new, so they would require a bit of guidance. (Steven Gan, personal interview, 20 May 2015)

For TMI, the news process is more hierarchical and traditional. There is a clear role of Sadiq as the sole gatekeeper who makes the decision of what is in and what is out of the online newshole. This is further underscored by former TMI journalist, Zurairi Abdul Rahman, who was one of the news portal reporters during the 2013 election.

It is a pyramid, and I sit at the top of the pyramid. Every report that went out during the election campaign, during the timeline you specified, all had to go through me. If I think it is wrong, or it is off, I will say no, please rewrite it this way or I will rewrite it myself. (Jahabar Sadiq, personal interview, 26 October 2015)

The way we operate is that you should always just report, and the ones who will make the call will be the news editors in charge that day...they just send it in, and if the editor decides that it is not suitable, then you either re-write or kill the story. (Zurairi Abdul Rahman, personal interview, 20 October 2015)

\section{Conclusion}

Findings show that the notion of a 'gate' in the journalistic practice of two of the most popular news portals in Malaysia, MalaysiaKini and TMI, remains intact. Although the reporting of both news portals is contingent upon multiple explanatory factors as explained by the hierarchy of influence model, the editor-in-chief still holds immense power in deciding what information people can and cannot read. This is in line with previous studies concluding that journalists are retaining all or part of their gatekeeping roles as they move online, including the practice of story assignment and copy editing, reproducing those of their print counterparts $[6,12,25]$. The gatekeeping processes are more vital than ever in MalaysiaKini and TMI. In TMI, the editor acts as the sole 'Mr Gate' in deciding what news should be in or out.

Although the journalistic framework of both online news portals is still based upon traditional journalistic ideological practices such as fair, balanced, and objective reporting, the news content is counter-ideological. Since the gatekeeping process remains strong, this counter-ideological strategy is mostly decided at the news-editor level.

This article posits that the constant need to generate a counter-ideological flow of news while negotiating the risk of defamation, libel, and slander due to media laws in Malaysia means that it is imperative that both news portals retain all or part of their gatekeeping roles. In line with arguments by Singer [25], the sheer quantity of news that can be featured online, along with its wildly varying quality prepared particularly by rookie reporters, reinforces the need for ' $\mathrm{Mr}$ Gates' to sort it out.

\section{References}

1. J.Abbott. Democracy@ internet. org Revisited: analysing the socio-political impact of the internet and new social media in East Asia, Third World Quarterly, 33, 2(2012)

2. J.Abbott. J. Contemp. Asia, 43, 4, (2013)

3. About The Malaysian Insider (n.d.) Available from http://www.themalaysianinsider.com/about/, Accessed 1 December 2015.

4. M.K.Anuar. Politics and the Media in Malaysia, Philippine Journal of Third World Studies, 20, 1, (2005)

5. L.Barkho. Unpacking the Discursive and Social Links in BBC, CNN and Al Jazeera's Middle East Reporting, Journal of Arab and Muslim, 1, 1, 11 (2007)

6. P.J.Boczkowski. J. Commun, 54, 2, 197 (2004)

7. A.Bruns .BJR, 7, 2, (2011)

8. W.P.Cassidy Gatekeeping similar for online, print journalists. Newspaper Research Journal, 27,2 (2006)

9. L.Chen. Int Rev Appl Linguist Lang Teach, 43, 33 (2005)

10. D.V.Dimitrova \& M.Neznanski.. J Comput Mediat Commun, 12, 1, 248 (2006) 
11. D.V.Dimitrova, C.Connolly-Ahern, A.P.Williams, L.L.Kaid, \& A. Reid. Hyperlinking as gatekeeping: Online newspaper coverage of the execution of an American terrorist. Journalism Studies, 4,3, 401 (2003)

12. D.Domingo, T.Quandt, A.Heinonen, S.Paulussen, J.B.Singer \& Vujnovic, M. Participatory journalism practices in the media and beyond: An international comparative study of initiatives in online newspapers. Journalism Practice, $2,3,326(2008)$

13. N.Fairclough. Language and power. Pearson Education (2001)

14. S.Giersdorf \& A.Croissant. a. Journal of Civil Society, 7,1 (2011)

15. K.Lewin. Group decision and social change. Readings in social psychology, 3 (1947)

16. S.Loone. Anwar vows no retributive justice for political foes. Malaysiakini. (2013)

17. W.D.Manning. The Gate Keeper. Journalism and Mass Communication Quarterly, 27, 4 (1950)

18. MalaysiaKini.Najib's ratings slide, BR1M not working. (2013)

19. D.Matheson. Media discourses. McGraw-Hill Education (2005)

20. O.Mok. Anwar says peaceful transition if Pakatan takes power. The Malaysian Insider. (2013)

21. S.D.Reese. Understanding the global journalist: A hierarchy-of-influences approach. Journalism Studies, 2, 2 (2013)

22. S.D.Reese. BJR, 3, 2 (2007).

23. P. J.Shoemaker \& S.D. Reese . Mediating the message. White Plains: Longman. (1996).

24. J. B. Singer. Online journalists. Journal of Computer-Mediated Communication, 4,1 (1998)

25. J B. Singer. Stepping back from the gate: Online newspaper editors and the co-production of content in campaign 2004. Journalism \& Mass Communication Quarterly, 83, 2 (2006)

26. J. Steele. The International Journal of Press/Politics, 14, 1 (2009).

27. The Malaysian Insider. BN, Pakatan in dead heat for Election. (2013).

28. The Rakyat Post. Malaysian Insider joins the Edge Media Group. June 9. Available from http://www.therakyatpost.com/business/2014/06/09/malaysian-insider-joins-edge-media-group/, accessed 1 December 2015 (2014)

29. D. M. White. Journalism and Mass Communication Quarterly, 27,4, (1950) 